\title{
Failure Rate Estimates for Passive Mechanical Components
}

\author{
L. C. Cadwallader
}

October 2018

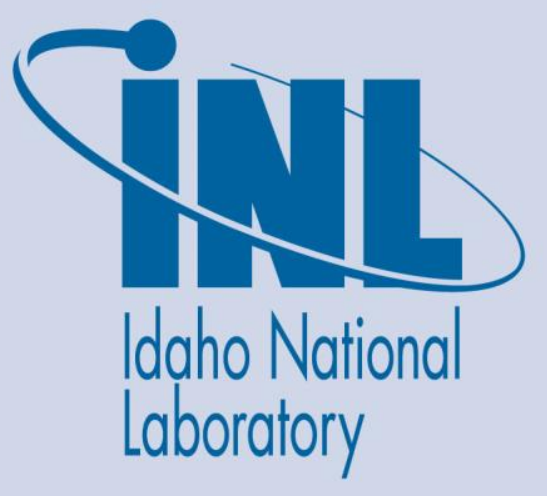

The INL is a U.S. Department of Energy National Laboratory operated by Battelle Energy Alliance 
Disclaimer

This information was prepared as an account of work sponsored by an agency of the U.S. Government. Neither the U.S. government nor any agency thereof, nor any of their employees, makes any warranty, expressed or implied, or assumes any legal liability or responsibility for the accuracy, completeness, or usefulness, of any information, apparatus, product, or process disclosed, or represents that its use would not infringe privately owned rights. References herein to any specific commercial product, process, or service by trade name, trade mark, manufacturer, or otherwise, does not necessarily constitute or imply its endorsement, recommendation, or favoring by the U.S. Government or any agency thereof. The views and opinions of authors expressed herein do not necessarily state or reflect those of the U.S. government or any agency thereof. 


\title{
Failure Rate Estimates for Passive Mechanical Components
}

\author{
L. C. Cadwallader
}

October 2018

Idaho National Laboratory

Fusion, Hydrogen \& Measurement Sciences

Idaho Falls, Idaho 83415

http://www.inl.gov

Prepared for the

U.S. Department of Energy

Office of Science

Under DOE Idaho Operations Office

Contract DE-AC07-05ID14517 



\begin{abstract}
Fusion design projects that reach the stage of design reviews typically require reliability, availability, maintainability and inspectability (RAMI) assessments. While many kinds of reliability and maintainability data are needed for a wide variety of fusion components to quantify a RAMI assessment, one of the types of components requiring data is the passive mechanical component. Passive mechanical components can be items such as metal plates, rods, shafts, brackets, bolts, and other items. Generally these passive components tend to have low failure rates since they are simple designs, have no or few moving parts, and do not need control signals to perform their design function. However, there are no widely recognized datasets for such components, so analysts must use multiple datasets and judgment for failure rates. This report gives recommended failure rates for various failure modes of these components, and gives suggested failure rate multipliers to apply to these failure rates if they reside in harsh environments. If the component resides far from the tokamak then typical industrial failure rates would suffice. Components near the tokamak find conditions can be demanding; similar to those in a fission reactor containment building. Some component failure rates can be modified if the components reside inside the tokamak.
\end{abstract}




\section{CONTENTS}

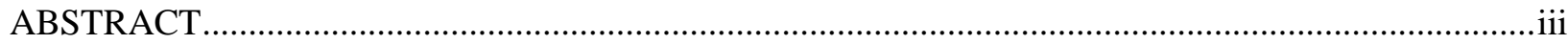

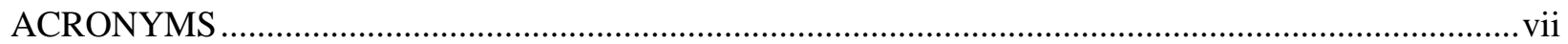

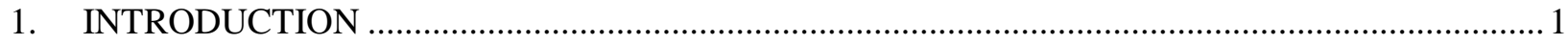

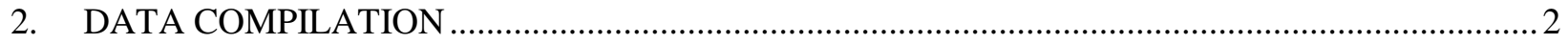

3. FAILURE RATE ADJUSTMENT FACTORS ….................................................................... 7

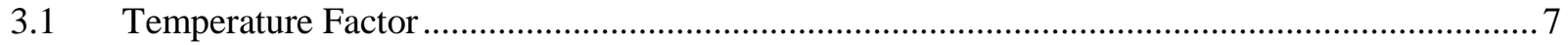

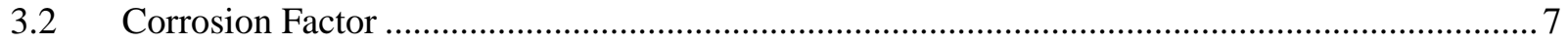

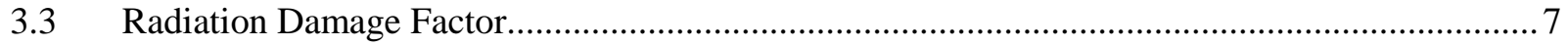

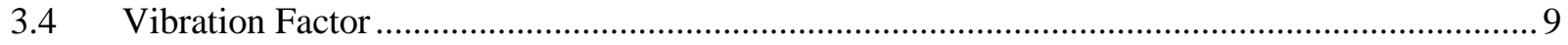

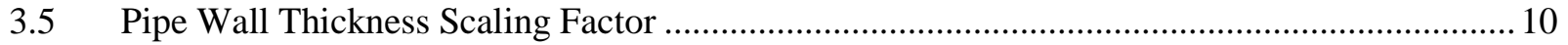

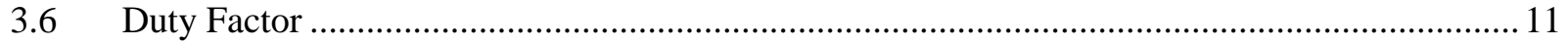

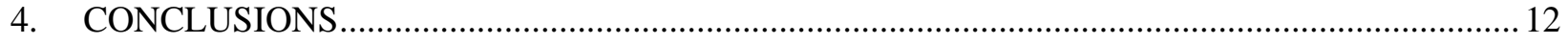

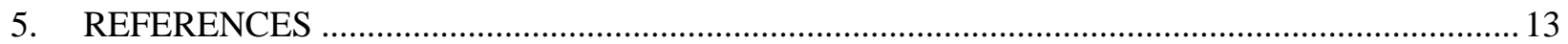

TABLES

1. Recommended mean failure rates for selected passive mechanical components. ................................. 3

2. Suggested failure rates for several passive mechanical components. ................................................ 4

3. Some failure rate modifiers for radiation environments (IEEE 1984) .............................................. 9 


\section{ACRONYMS}

DN diameter nominal

ITER the ITER International Project, see www.iter.org

JET Joint European Torus

Mhr million hours

m-hr meter-hour

$\mathrm{Nd}$ :YAG neodymium-doped:yttrium aluminum garnet

RAMI reliability, availability, maintainability, inspectability 


\section{Preliminary Failure Modes, Effects, and Criticality Analysis of the U.S. Fueling Pellet Injection System Confinement Cask}

\section{INTRODUCTION}

Performing reliability studies for some ITER systems (Cadwallader 2013a; Cadwallader 2014; Cadwallader 2015; Cadwallader 2018) has shown that data on passive components is needed. The International Atomic Energy Agency gives the definition of a passive component as a component whose function does not depend on an external input such as actuation, mechanical movement, or supply of power (IAEA 2000). Considering mechanical components, passive components are usually long-life metallic parts such as brackets, bearings, pipes, tanks, heat exchangers, rods, shafts, plates, nozzles, etc. Rotating and reciprocating shafts are included even though by strict definition a passive component does not depend on movement. In general, if the service environment does not degrade a passive metal component (e.g., rust), and the stresses on the component are within its design values, it is conceivable that a metal component could have a very long lifetime, perhaps equaling the life of a facility. It is noted that a passive mechanical component can also be a short-lived part such as a filter or screen. Such components are replaced by either preventive maintenance (e.g., replaced when a schedule requires replacement) or corrective maintenance (replaced when the part has failed to function).

There are several published data compilations that include some failure rate data on passive mechanical components. Several published documents that present independent data values have been collected to perform a combination of the data values via the geometric mean approach so that one recommended value is produced. Typical industrial failure rates can apply to components that reside far from the tokamak and that are not exposed to extreme environments. For components closer to the tokamak, $\mathrm{k}$ factor multipliers to adjust the failure rates for harsh environments have also been examined. Analysts can use $\mathrm{k}$ factor relations to develop recommended failure rate values to account for radiation damage, the thermal environment, vibration, and other environment factors for areas close to, and inside, the tokamak. These $\mathrm{k}$ factor values can be used on failure rates from more benign environments to apply the data to RAMI assessments of fusion systems.

Another concern with mechanical components is joining these components to fashion more complex devices or to effect functions of simple components, such as brackets or pipe hangers. Often the most preferred method of joining is welding. Some failure rate data on welds is cited in this article. Another method of joining is mechanical joints, the most well-known of which is bolt-and-nut. Failure rate data on bolts and nuts are included here. Mechanical failure of bolts can have several failure modes, including mechanical overstress failure during assembly, mechanical failure at elevated temperature, corrosion that weakens a bolt, stress-corrosion cracking, and fatigue failure (Bickford 1995).

An important issue to account for when seeking failure rate data for passive mechanical components is the component operating environment, factors such as high radiation, high temperature, high or low pressure, etc. This report gives failure rate values and suggested multipliers for those values to account for the fusion environment. 


\section{DATA COMPILATION}

Several data sources (Moss 2005; Harris 1984; Smith 2017; Dexter and Perkins 1982; NSWC 2010; Exida 2012; Mahar 2011) noted to contain information on mechanical components were used to build a set of failure rates by failure mode for each of these components. Some data sources are more aged than others, but are nonetheless considered to be important for this line of inquiry. Some of the data sources did not define the failure mode, so the failure rate is considered to be all failure modes combined, but usually this is manifest by 'failure to operate' or 'loss of mechanical integrity'. That is, the failure mode is that the component breaks or otherwise fails to perform its primary function. Where possible, when the components were well defined and clearly well aligned among multiple data sources, a geometric mean was used to produce an average value for the failure rate from the collected data sources. These geometric mean data are recommended and are presented in Table 1. The reader will note that the failure rates in Table 1 are per million hours (Mhr). This nomenclature was used since passive component failure rates tend to be lower values than the failure rates for active mechanical components. The failure rates in Table 1 tend to come from industrial applications, so the environments are assumed to be indoors, typically 20-30 C temperature unless the component is part of an engine or large machine, air atmosphere at sea level pressure, moderate humidity, and no irradiation. Other passive component data were found in single sources and are given in Table 2. These data are suggested data to use when there are no geometric mean data available. To apply these failure rates for more aggressive environments, adjustments are needed to account for operating environment factors such as elevated temperature, corrosion, and irradiation influence the failure rates. The adjustment multipliers are referred to as ' $\mathrm{k}$ factors', and some $\mathrm{k}$ factor guidance to calculate multiplier values is given in this report.

Bünde, Fabritsiev, and Rybin (1991) wrote a useful paper on welding and brazing reliability. From traditional nuclear fission operating experiences, reference and upper bound values are

- Longitudinal welds of pipes, $\approx 5 \mathrm{E}-08 / \mathrm{hr}-\mathrm{m}$ with an upper bound of $5 \mathrm{E}-07 / \mathrm{hr}-\mathrm{m}$

- Butt welds of pipes, $\approx 5 \mathrm{E}-09 / \mathrm{hr}$-weld with an upper bound of $1 \mathrm{E}-07 / \mathrm{hr}-$ weld

These values are for small leaks and apply to low stress loaded material, nuclear technology quality level, conventional nuclear welding (arc welding, such as tungsten inert gas welding), and pre-operation shop welds. Bünde, Fabritsiev, and Rybin (1991) also gave some multiplicative factors:

- Large leak failure mode is $1 \mathrm{E}-01 \times$ the small leak failure mode value

- Weld rupture failure mode is $1 \mathrm{E}-02 \times$ a small leak failure mode value

- High stress loaded materials are $10 \times$ the low stress loaded failure rate value

- Conventional welding technology is $10 \times$ the nuclear welding technology failure rate value

- Highest quality control class is $1 \mathrm{E}-01 \times$ the next lower quality control class

Schnauder, Nardi, and Eid (1997) gave some weld average failure rate data for combined failure modes of leak and loss of integrity. These values were based on a consensus of reliability experts participating in an availability assessment of fusion blankets. These values apply to fusion blanket environments (high radiation, high heat, mechanical stress, vibration):

- Electron beam weld, 1E-09/m-hr

- Diffusion (solid state) weld, $1 \mathrm{E}-08 / \mathrm{m}-\mathrm{hr}$ 
Table 1. Recommended mean failure rates for selected passive mechanical components.

\begin{tabular}{|c|c|c|c|}
\hline Component Name & Failure Mode & $\begin{array}{l}\text { Geometric Mean } \\
\text { Failure Rate } \\
\text { (per Mhr) }\end{array}$ & $\begin{array}{l}\text { Upper Bound } \\
\text { Failure Rate } \\
\text { (per Mhr) }\end{array}$ \\
\hline Accumulator tank, atmospheric & All modes & 0.35 & 0.45 \\
\hline Ball bearings, light use & $\begin{array}{l}70 \% \text { fatigue, wear; } \\
20 \% \text { binding; } 7 \% \\
\text { scoring; } 3 \% \text { corrosion }\end{array}$ & 1.1 & 11 \\
\hline Ball bearings, heavy use & All modes & 0.33 & Not given \\
\hline Bellows & Leak & 3.7 & 7.4 \\
\hline Bolt and nut & $\begin{array}{l}90 \% \text { loosen, } 10 \% \\
\text { break }\end{array}$ & 0.02 & 2 \\
\hline Cam & $\begin{array}{l}50 \% \text { wear, } 50 \% \\
\text { fracture }\end{array}$ & 0.1 & Not given, assume 1 \\
\hline $\begin{array}{l}\text { Cap, protective, metal } \\
\text { (also called dust cap) }\end{array}$ & All modes & 0.04 & 0.06 \\
\hline Coupling, mechanical & All modes & 5.2 & Not given, assume 52 \\
\hline Discharge nozzle & Leak or break modes & 0.5 & Not given, assume 5 \\
\hline \multirow[t]{2}{*}{ Filter, wire screen } & Internal leak & 1.6 & 9 \\
\hline & blockage & 0.9 & 3 \\
\hline \multirow[t]{2}{*}{ Fire sprinkler head } & $\begin{array}{l}\text { All modes for hourly } \\
\text { operation }\end{array}$ & 0.3 & Not given, assume 3 \\
\hline & $\begin{array}{l}\text { Fail to operate on } \\
\text { demand }\end{array}$ & $0.02 /$ demand & Not given \\
\hline Helical gear & $\begin{array}{l}61.2 \% \text { tooth breakage, } \\
20.3 \% \text { surface fatigue, } \\
13.2 \% \text { wear, } 5.3 \% \\
\text { plastic deformation }\end{array}$ & 0.3 & 1.3 \\
\hline Key, for keyway in a shaft & $\begin{array}{l}80 \% \text { deflection, } 20 \% \\
\text { break }\end{array}$ & 0.02 & $\begin{array}{l}\text { Not given, assume } \\
0.35\end{array}$ \\
\hline Orifice plate & blockage & 0.09 & 0.6 \\
\hline Pin, metal & Shear/fracture & 2 & 3 \\
\hline Roller bearing & $\begin{array}{l}70 \% \text { fatigue, wear; } \\
20 \% \text { binding; } 7 \% \\
\text { scoring; } 3 \% \text { corrosion }\end{array}$ & 0.09 & 6 \\
\hline \multirow[t]{2}{*}{ Rupture disk } & Leak or break modes & 7.5 & 100 \\
\hline & $\begin{array}{l}\text { Fail to open on } \\
\text { demand }\end{array}$ & $1 \mathrm{E}-04 /$ demand & Not given \\
\hline Shaft, metal, low stress, rotating & Breakage/fracture & 0.07 & 5 \\
\hline Shaft, metal, high stress, rotating & Breakage/fracture & 2.2 & 66 \\
\hline Sleeve bearing & $70 \%$ binding, $30 \%$ play & 0.17 & 1 \\
\hline Spur gear & $\begin{array}{l}50 \% \text { tooth breakage, } \\
50 \% \text { binding }\end{array}$ & 0.5 & 9 \\
\hline
\end{tabular}


Table 2. Suggested failure rates for several passive mechanical components.

\begin{tabular}{|c|c|c|c|}
\hline Component Name & Failure Mode & $\begin{array}{c}\text { Average } \\
\text { Failure Rate } \\
\text { (per Mhr) }\end{array}$ & $\begin{array}{c}\text { Upper Bound } \\
\text { Failure Rate } \\
\text { (per Mhr) }\end{array}$ \\
\hline Baffle & All modes & 0.44 & Not given, assume 4.4 \\
\hline Bracket & Mechanical failure & 0.2 & 0.5 \\
\hline Bus duct, per unit & All modes & $1.3 \mathrm{E}-04$ & $\begin{array}{l}\text { Not given, assume } \\
1.3 \mathrm{E}-03\end{array}$ \\
\hline Clamp & All modes & 2 & Not given, assume 20 \\
\hline Clip & All modes & 5.1 & 15.1 \\
\hline Gasket, low pressure & $\begin{array}{l}70 \% \text { minor leak, } 30 \% \\
\text { major leak }\end{array}$ & 0.01 & Not given, assume 0.1 \\
\hline Gasket, spiral wound & $\begin{array}{l}70 \% \text { minor leak, } 30 \% \\
\text { major leak }\end{array}$ & 0.01 & Not given, assume 0.1 \\
\hline Hatch, steel & Loss of integrity & $6 \mathrm{E}-05$ & $6 \mathrm{E}-04$ \\
\hline Hatch gasket & Fail to seal & $6 \mathrm{E}-04$ & $6 \mathrm{E}-03$ \\
\hline Hydraulic fitting & Al modes & 0.24 & Not given, assume 2.4 \\
\hline Mounting adapter & $\begin{array}{l}50 \% \text { fracture, } 50 \% \\
\text { deflection }\end{array}$ & 0.003 & Not given, assume 0.03 \\
\hline $\begin{array}{l}\text { Penetration feedthrough for gas } \\
\text { tubing }\end{array}$ & Fail to seal & 0.1 & 1 \\
\hline $\begin{array}{l}\text { Penetration feedthrough for } \\
\text { sensor tap line }\end{array}$ & Fail to seal & 0.1 & 1 \\
\hline \multirow{4}{*}{$\begin{array}{l}\text { Penetration feedthrough for } \\
\text { multiple-pin electrical cable }\end{array}$} & Open circuit & 0.2 & 2 \\
\hline & Short circuit & 0.08 & 0.8 \\
\hline & Intermittent circuit & 0.12 & 1.2 \\
\hline & Fail to seal & 0.125 & 1.25 \\
\hline \multirow{4}{*}{$\begin{array}{l}\text { Penetration feedthrough for } \\
\text { coaxial cable }\end{array}$} & Open circuit & 7.7E-04 & 7.7E-03 \\
\hline & Short circuit & $3.1 \mathrm{E}-04$ & $3.1 \mathrm{E}-03$ \\
\hline & Intermittent circuit & $4.6 \mathrm{E}-04$ & 4.6E-03 \\
\hline & Fail to seal & 0.125 & 1.25 \\
\hline Pinion in rack-and-pinion & $\begin{array}{l}50 \% \text { bind, } 50 \% \text { loss of } \\
\text { drive }\end{array}$ & 0.03 & Not given, assume 0.3 \\
\hline Quick disconnect pipe fitting & Leakage & 2.4 & Not given, assume 24 \\
\hline Rack in rack-and-pinion & $\begin{array}{l}50 \% \text { bind, } 50 \% \text { loss of } \\
\text { drive }\end{array}$ & 0.03 & Not given, assume 0.3 \\
\hline Reciprocating piston rod & $70 \%$ bind, $30 \%$ fracture & 0.001 & Not given, assume 0.01 \\
\hline Rivet & Fatigue failure & 0.08 & Not given, assume 0.8 \\
\hline Rod & Breakage & 0.02 & Not given, assume 0.2 \\
\hline Steel plate & All modes & 0.01 & Not given, assume 0.1 \\
\hline Spacer, metal & All modes & 0.7 & 4.1 \\
\hline Thrust shaft & $\begin{array}{l}50 \% \text { breakage, } 50 \% \\
\text { deflection }\end{array}$ & 0.025 & Not given, assume 0.25 \\
\hline
\end{tabular}

Schnauder, Nardi, and Eid (1997) also gave a relation to find an equivalent overall failure rate for welding if there were double welds, such as to form an interspace between plates or an annulus between tubes. This relation only holds if the failure rates and repair rates are the same for the 2 welds: 
Equivalent failure rate, $\lambda \mathrm{e}=\lambda[(2 * \lambda / \mu)]^{0.5}$

where

$\lambda=$ the failure rate of one of the 2 welds

$\mu=$ the repair rate of one of the 2 welds

In risk assessment work, the trend is to include welds with piping, as shown by the treatment in an industry-average failure rate data report (Eide et al. 2007). However, some work has focused on the reliability of welds produced by arc welding for nuclear technology. Grosselin et al. (2007) discussed weld reliability estimates for butt welded primary coolant piping. Estimated frequency values for weld leakage on this large diameter (e.g., 1-m diameter), arc welded stainless steel piping ranged from 3E-09/weld-hr to 7E-13/weld-hr. These values came from fracture mechanics computer code estimates that were tempered with operating experience information. The range of the Grosselin et al. (2007) estimates show that the Bünde, Fabritsiev, and Rybin (1991) recommended butt weld value is just above the high end of the estimated range. The Schnauder, Nardi, and Eid (1997) values are within the Grosselin et al. (2007) ranges. The Bünde, Fabritsiev, and Rybin (1991) and Schnauder, Nardi, and Eid (1997) values are acceptable to use as a first approximation of weld failure rates, especially for scoping studies. If more accuracy is sought, the analyst will have to develop a data set for the particular type of weld, the material, and the application. Alternatively, the analyst could also use a fracture mechanics code if the code addresses the fusion materials.

Fusion designers sometimes consider other types of welding besides traditional arc welding. Electron beam welding is a welding process where high energy electrons heat the work pieces to be joined and the work pieces melt and flow together. E-beam welding is well suited to tubing and is good to depths of perhaps $300 \mathrm{~mm}$. This type of welding generally uses vacuum around the work pieces so that the electron energy remains high (Weglowski, Blacha, and Phillips 2016). Laser welding is also used. In general, pulsed neodymium-doped:yttrium aluminum garnet (Nd:YAG) lasers are used for microwelding (Shannon 2016). Peak power for Nd:YAG lasers can vary from 0.25 to $3 \mathrm{~kW}$ for penetration into the work piece and pulse width for weld width can vary between 0.1 to $5 \mathrm{~ms}$. Continuous wave laser welding is generally performed with a carbon dioxide laser of 1 to $6 \mathrm{~kW}$. Laser welding can penetrate up to $6 \mathrm{~mm}$ and greater in steels (Shannon 2016). Bachmann, Gumenyuk, and Rethmeier (2016) discussed that high power solid state lasers are reliable using joining approaches that are designed to take advantage of their high power (up to $100 \mathrm{~kW}$ ) and high brightness (<15 mrad) that can single-pass weld sections 15 $\mathrm{mm}$ to $20 \mathrm{~mm}$ thick and larger. Even $50 \mathrm{~mm}$ thickness is possible using a double-sided single pass technique. Concentrated laser energy allows for narrow, deep welds and fast welding (faster than arc welding), similar to e-beam welding but vacuum is not needed.

Cadwallader (2010) generated a failure rate for some longitudinal electron beam welds used in hypervapotrons on the Joint European Torus (JET) machine; the average failure rate value was $3 \mathrm{E}-08 / \mathrm{hr}$ $\mathrm{m}$, with an upper bound of $2 \mathrm{E}-07 / \mathrm{hr}-\mathrm{m}$. The e-beam welds were performed in vacuum. Bünde, Fabritsiev, and Rybin (1991) suggested using 1E-01 multiplier to be applied to the nuclear welding values to account for new technology e-beam welding; e-beam welding is reputed to have a smaller heataffected zone of metal when joining work pieces than arc welding. For longitudinal welding the $1 \mathrm{E}-01$ multiplier would give an average failure rate of $5 \mathrm{E}-09 / \mathrm{hr}-\mathrm{m}$, which is a lower value than the operating experience from the JET machine. The comparison of the two average failure rates is ranked as fair or general agreement (within a factor of 10) (see Cadwallader and Pinna 1999). It is possible that with more years of operating time and no weld failures the JET failure rate value would be reduced further but it is unlikely that the value would reduce by a factor of 10 , so the comparison would remain fair rather than good. A good comparison is within a half order of magnitude (see Cadwallader and Pinna 1999). 
Laser welding has been used in various industries. The automotive manufacturing industry treats laser welding as a high flexibility, easily automated technique that has minor influence on the work piece, it is an established, reliable procedure in the manufacture of automobiles (Haferkamp, Meier, and Harley 2007). Despite literature searches, no data sets on laser welds were located to develop a failure rate. Kirk et al. (2018) suggests that laser welds are reliable, fast, and have a small heat affected zone. Therefore, given this information, the author infers that laser welds are at least as reliable as arc welds.

Cadwallader (2010) also calculated some braze failure rates of stainless steel tubing brazed to $\mathrm{CuCrZr}$ tubing. These were low stress lines and the failures were small leaks of the water coolant in the lines. The average failure rate was 9E-08/joint-hr and the upper bound was $3 \mathrm{E}-07 /$ joint-hr.

In some cases the risk or RAMI analyst will have to make assumptions and use analyst judgement for component failure rates of components with no operating experience. Bloch and Geitner (2006) gave some guidance to allow numerical interpretation of subjective reliability terms:

Extremely reliable $\quad 0.01$ per Mh

Highly reliable, ok in large numbers $\quad 0.01$ to 0.1 per $\mathrm{MH}$

Good reliability for moderate numbers $\quad 0.1$ to 1.0 per Mh

Average reliability, ok in small numbers $\quad 1.0$ to 10 per Mh

Very unreliable 10 to 100 per Mh

Intolerable reliability $\quad>100$ per $\mathrm{Mh}$

This guidance can support the analyst when making judgements after discussions with designers. As can be seen by comparison with the values listed in Tables 1 and 2, passive mechanical components are generally at the highly reliable and extremely reliable end of this spectrum. 


\section{FAILURE RATE ADJUSTMENT FACTORS}

In reliability estimation, a basic failure rate can be adjusted by a multiplicative factor to account for the specific operating conditions or a new operating environment. These multiplicative factors are referred to as "k factors". Perhaps the most famous use of k factors is found in Military Handbook 217, where the temperature, application (ground, vehicle, airborne, etc.), component quality, and other conditions are taken into account by use of these multiplicative factors (MIL-HDBK 1991). The companion document for mechanical components is published by the US Naval Surface Warfare Center (NSWC 2010). Some important experimental work done on past spacecraft components to define k factor values is found in reference (NASA 1971). Cadwallader has explored models for various $\mathrm{k}$ factors (Cadwallader 2010; Cadwallader 2013b; Cadwallader 2013c). The primary k factor models are discussed below.

\subsection{Temperature Factor}

An Arrhenius exponential equation method to account for the temperature difference is given in Cadwallader (2010):

$\lambda_{2} / \lambda_{1}=\exp \left[B \times\left(1 / T_{1}-1 / T_{2}\right)\right]$

where

subscript 1 = the known failure rate and operating temperature

subscript 2 = the unknown failure rate and new operating temperature of the other application.

From Cadwallader (2010), the B constant can be taken as $1623.39 \mathrm{~K}$ from operating experience data for steel piping. This factor can be applied to other steel parts as well.

\subsection{Corrosion Factor}

Corrosion of components in fission reactor systems has undergone much study. The basic approach to corrosion reduction is selecting corrosion resistant materials and chemical additions to cooling water to reduce the radicals created by radiolysis of the water (Feron 2012). Most of the mechanical parts discussed here are not cooling system components. For corrosion of cooling system components, Cadwallader (2013a) discusses an approach to estimate a corrosion $\mathrm{k}$ factor in flowing water media.

Corrosion in non-coolant systems, such as structural components in room air or components in other systems (e.g., a plasma fueling system), is generally a slower phenomenon than in water cooling systems and is taken into account in the typical failure rate value. The corrosion mechanism is the same, electrochemical/galvanic corrosion, but atmospheric humidity provides the electrolyte rather than copious amounts of water coolant that may contain oxidizing (e.g., $\mathrm{OH}^{-}$and reducing (e.g., $\mathrm{H}^{+}$) radicals created by radiolysis. Since corrosion can take decades to weaken a component from the surface inward; it may not be the most crucial factor for passive metal components. If the analyst believes there is a significant corrosion concern, then a $\mathrm{k}$ factor can be assigned to account for high corrosion.

\subsection{Radiation Damage Factor}

Radiation damage, particularly neutron damage in metals, is an important concern for the long term reliability of components. If information on actual irradiated components is available, this information should be reduced into failure rates. Some information on bolts in high radiation conditions is reported below, and the cracking (breaking) failure rate of irradiated bolts was more than a factor of 10 greater than the bolt failure rate value given in Table 1. If no specific information is available, then estimation using component failure rates adjusted for radiation damage can be used. 
Zinkle and Busby (2009) discussed the radiation damage processes that occur in structural materials at different temperatures and fluence levels. The radiation hardening and embrittlement are generally the low temperature phenomena of concern (that is, at less than 0.3 to $0.4 \mathrm{~T}_{\text {melt }}$ when $\mathrm{T}_{\text {melt }}$ is in Kelvin) when neutron damage is $>0.1 \mathrm{dpa}$. Other phenomena emerge at higher temperatures and dpa levels. In general, materials are often used at less than 0.4Tmelt since the yield strength is high at these lower temperatures. Therefore, factors to account for hardening and embrittlement are suggested to modify the base failure rates for mechanical components.

Radiation damage will affect two important properties of metal components: the strength and embrittlement. The failure rate modifiers will follow the approach used by Lauridsen, Christensen, and Kongso (1996). The radiation degradation factor, $\Delta$, is

$\Delta=\left(P_{o}-P_{t}\right) /\left(P_{o}-P_{f}\right)$

where

$\mathrm{P}_{\mathrm{o}}=$ value of a characteristic parameter of the material before radiation exposure

$\mathrm{P}_{\mathrm{t}}=$ value of a characteristic parameter of the material after total radiation dose

$P_{f}=$ value of the characteristic parameter of the material at failure.

A factor of 10 will be applied to each characteristic parameter identified as an issue for radiation damage; this should result in a conservative estimate of the overall radiation damage. The radiation degradation factor is used as

Failure rate modifier for radiation damage $=10^{(\Delta)}$

The properties of a particular metal before and after irradiation can be taken from a radiation damage study. It is possible that alloy constituents may vary from the metal irradiated to the metal in the reliability study, but if the main constituents are close then data from the irradiation study will be approximate and can be used to estimate a $\mathrm{k}$ factor. For yield strength as a characteristic parameter, the parameter at component failure $\left(\mathrm{P}_{\mathrm{f}}\right)$ is assumed to occur at stress $=2 / 3 \times$ yield strength based on metals discussed in the ASME Boiler and Pressure Vessel Code. For elongation as a characteristic parameter, the Pf value is set with conservatism. Juvinall and Marshek (1991) suggested that a safety factor of 2 or even 3 be used with brittle material and that if elongation drops below 10\%, the design should be examined for the possibility of using a less brittle material. Failure can be assumed when a safety factor of 2 is multiplied with an elongation of $10 \%$, or $\mathrm{P}_{\mathrm{f}}=0.2$.

Then the failure rate multiplier for each property is

General failure rate modifier for yield strength radiation damage $=10^{(\Delta)}$

Failure rate modifier for elongation radiation damage $=10^{(\Delta)}$

These failure rate modifiers are multiplied to develop a full radiation damage multiplier.

If the components are residing in low radiation areas such as an ITER port cell rather than closer to the ITER vacuum vessel, the neutron fluence would be low. The effects on metal components would be less than at high fluence and radiation heating. Some failure rate modifiers were surveyed from a data 
compilation (IEEE 1984) and Table 3 below gives the results for some active and passive components (Cadwallader 2013a).

Table 3. Some failure rate modifiers for radiation environments (IEEE 1984).

\begin{tabular}{|c|c|}
\hline Component Type & k factor Failure Rate Multiplier \\
\hline Annunciators & 1.1 to 2.0 \\
\hline Batteries & 1.05 to 1.2 \\
\hline Blowers & 1.0 \\
\hline Circuit breakers & 1.17 to 5.0 \\
\hline Motors & 1.0 \\
\hline Heaters & 1.0 \\
\hline Transformers & 1.07 to 1.57 \\
\hline Valve actuators & 1.1 to 2.06 \\
\hline Instrumentation \& Controls & 1.0 to 1.25 \\
\hline Cables & 2.0 to 3.7 \\
\hline \multicolumn{2}{|c|}{$\begin{array}{l}\text { Note: The radiation environment is that found in the interior of a containment } \\
\text { building of a nuclear fission power plant. This environment includes both MeV } \\
\text { gamma and } 10-100 \mathrm{keV} \text { neutron fluxes. The combined radiation field is on the } \\
\text { order of } 0.1 \text { to } 0.25 \mathrm{~Sv} / \mathrm{hr} \text {, where } \approx 10 \% \text { is due to neutrons and the remainder is } \\
\text { gamma radiation (Prince } 2012) \text {. This dose rate range is converted to fluence by } \\
\text { conversion factors given by Tsoulfanidis }(1983) \text { and assuming a } 20 \text {-yr component } \\
\text { lifetime. The neutron fluence ranges are } 1 \mathrm{E}+13 \text { to } 1 \mathrm{E}+14 \mathrm{n} / \mathrm{cm}^{2} \text { and the gamma } \\
\text { fluence ranges are } 1 \mathrm{E}+15 \text { to } 1 \mathrm{E}+19 \mathrm{\gamma} / \mathrm{cm}^{2} \text {. The neutron flux is in fair agreement } \\
\text { with measurements made by Scherpelz and Tanner (2002).n }\end{array}$} \\
\hline
\end{tabular}

Some active components such as blowers, motors and heaters have no effects from the mild environmental exposure of a fission power plant containment building. Some other active components have low $\mathrm{k}$ factor values that show the environment does not debilitate the components very much. Some passive components such as transformers, show a k factor of up to 1.57 , which is a small increase in the failure rate. Cables are also passive, but due to radiation damage effects on cable polymer insulation, the largest $\mathrm{k}$ factor is about double that of the transformer. For simple metal components such as those listed in Tables 1 and 2, for the mildly aggressive environment of a fission power plant containment building, or an analogous fusion environment (e.g., a port cell) the analyst can safely assume a radiation damage $\mathrm{k}$ factor of 2 .

Analysis of sets of stainless steel 316L bolt failures in the high temperature $(\approx 300 \mathrm{C})$ and high radiation environment of fission reactor baffles near the reactor core (neutron fluence between $2 \mathrm{E}+21 \mathrm{n} / \mathrm{cm}^{2}$ to $1.2 \mathrm{E}+22 \mathrm{n} / \mathrm{cm}^{2}$ ) has been performed (Cadwallader 2015). Removing the stress corrosion cracking failure mode (these fission bolts were in water coolant), the cracking failure rate of these bolts was $3.8 \mathrm{E}-08 /$ bolt-hr and the Chi-square $95 \%$ upper bound failure rate was $2.8 \mathrm{E}-07 / \mathrm{bolt}-\mathrm{hr}$.

\subsection{Vibration Factor}

FIDES (2010) gives a relation for a failure rate modifier to account for vibration. This formula is called Basquin's Law and is stated to apply to aluminum, copper, glass, ceramics, and other materials:

$A F=\left(g_{r m s} / g_{r m s 0}\right)^{1.5}$ 
$\mathrm{AF}=$ failure rate modifier for acceleration factors

$\mathrm{g}_{\mathrm{rms}}=$ the root mean square vibration amplitude (measured in gravities) in the operating environment

$\mathrm{g}_{\mathrm{rms} 0}=$ reference vibration amplitude.

The FIDES recommended $\mathrm{g}_{\mathrm{rms} 0}$ is $0.5 \mathrm{~g}$ for the materials listed above. This $\mathrm{k}$ factor can be applied to other metals besides aluminum and copper using the same reference amplitude of $0.5 \mathrm{~g}$.

\subsection{Pipe Wall Thickness Scaling Factor}

Sometimes fusion systems will use piping of varying thicknesses from other industrial applications. For example, fission feedwater pipe wall thickness is typically pipe schedule 40 (the carbon steel piping in that system is schedule 80 but the stainless steel pipe is schedule 40). ITER piping of diameter nominal (DN) $300 \mathrm{~mm}$ would have a wall thickness of $10.31 \mathrm{~mm}$ for Schedule 40. To account for pipe of a lesser wall thickness, the Thomas Method (Thomas 1981) is used in a manner mentioned by Moosemiller (2006). In early risk work in the 1980's and 1990's, the Thomas method gave good results for estimating the failure rate of piping (e.g., Johnson 1988; Medhekar, Bley, and Gekler 1993) and it has been used more recently as well (Vinod et al. 2004; AlSalamah, Shayan, and Savsar 2006). In the late 1990's when more data from piping operating experiences were compiled and analyzed, the risk assessment community has decided that the Thomas method should be secondary to experience data (Lydell 2000). However, when little or no operating experience data have been compiled for the piping under study, the Thomas Method remains a valid approach for piping failure rate estimation.

The Thomas Method gives the pipe leakage failure rate as being proportional to length, diameter, and wall thickness:

$P_{l e a k} \alpha(L \cdot D) / t^{2}$

where

$\mathrm{L}=$ length of pipe

$\mathrm{D}=$ diameter of pipe

$\mathrm{t}=$ thickness of pipe wall.

Thomas states that for prevailing pipe fabrication technology, the pipe has fewer, but larger size flaws as the pipe wall thickness increases. In general, the pipe failure rate decreases as the wall thickness increases (Fleming and Lydell 2006). If the pipe length and diameter are held constant and the change in the pipe leakage probability is sought for two different pipe wall thicknesses, then the ratio of Leak Probability for thickness $1\left(\mathrm{P}_{1}\right)$ to thickness $2\left(\mathrm{P}_{2}\right)$ is

$P_{1} / P_{2}=\left[\left(\mathrm{L}_{1} \cdot \mathrm{D}_{1}\right) / t_{1}^{2}\right] /\left[\left(\mathrm{L}_{2} \cdot \mathrm{D}_{2}\right) / t_{2}^{2}\right]$

As stated above, if the length $\mathrm{L}$ and diameter $\mathrm{D}$ are constant then they cancel out of the equation, leaving

$P_{1} / P_{2}=t_{2}^{2} / t_{1}^{2}$

Thus, the leak probability quotient is found to be a ratio of the thicknesses of the pipe walls. 
This relation can also be applied to other passive mechanical components such as braces, brackets, etc. The same behavior is found with thicker brackets, the thicker part carries stresses better and the probability of failure is lower for thicker parts.

\subsection{Duty Factor}

In general, a component is considered to operate for the entire time period of consideration, such as an 8,760-hr year. But, if the actual operating time over a time period of interest is known, then the estimated or actual operating time can be used to find the failure probability. An example is in the ITER RAMI calculations for failure occurrence probability, the actual system operating time in a year is estimated rather than assuming year-round operation. For some passive components, their design function may mean year-round operation. Some passive components may have a duty factor multiplier of the fraction of the year that the component is in operation. For some fusion systems, the operating time per year is assumed to be the time when the machine is at operating temperature for pulse operations; this is the time of high stress on components due to thermal and mechanical stress. The operating time per year would be a sum of the hours from the total number of campaigns where the machine operated for some time such as 10 hours per day for a short run of ten or twelve days per campaign. Some passive components in fusion systems may operate much longer in a year, for example a structural brace could be in operation for 8,760 hours per year. The analyst has to recognize what the duty factor is for a given component under study. 


\section{CONCLUSIONS}

This report has presented recommended and suggested component failure rate data for a variety of passive mechanical components. Some data on electrical feedthroughs has also been included since these components serve a mechanical barrier function in some design applications. The recommended data come from aggregation by geometric mean from independent data sources and are considered to be the best generic data available to use in RAMI or other reliability studies. The suggested data come from the data sources referenced in this report, but could not be averaged among independent data sources so the values originate from only one data source. However, these data have been generated from industrial operating experiences so they are considered to be better qualified than relying purely on analyst judgment. The suggested values are reported here for potential use in RAMI or other reliability studies.

This report also gives information to calculate $\mathrm{k}$ factors that can be used to adjust the basic failure rate values to account for different operating regimes and environmental conditions. Generally, the basic failure rates come from typical industrial conditions of modest temperature, modest humidity, modest vibration, modest stress, and high duty factor. The conditions in a fusion experiment system could be high temperature, modest to high humidity, modest to high vibration, modest to high stress, varying levels of irradiation, and likely a low duty factor. 


\section{REFERENCES}

AlSalamah, M. J., E. Shayan, and M. Savsar, 2006, "Reliability Analysis of a Cooling Seawater Pumping Station," International Journal of Quality and Reliability Management, 23, pp. 670-695.

Bachmann, M., A. Gumenyuk, and M. Rethmeier, 2016, "Welding with High-power Lasers: Trends and Developments," Physics Procedia, 83, pp. 15-25.

Bickford, J. H., 1995, An Introduction to the Design and Behavior of Bolted Joints, $3^{\text {rd }}$ edition, Boca Raton, Florida: CRC Press, Chapter 15.

Bloch, H. P., F. K. Geitner, 2006, Maximizing Machinery Uptime, Amsterdam: Elsevier, pp. 8588.

Bünde, R., S. Fabritsiev, and V. Rybin, 1991, "Reliability of Welds and Brazed Joints in Blankets and Its Influence on Availability," Fusion Engineering and Design, 16, pp. 5972.

Cadwallader, L. C., and T. Pinna, 1999, "Progress Toward a Component Failure Rate Data Bank for Magnetic Fusion Safety," Proceedings of the International Topical Meeting on Probabilistic Safety Assessment (PSA '99), Washington, DC, August 22-26, 1999, American Nuclear Society, LaGrange Park, Illinois, pp. 11-17.

Cadwallader, L., 2010, Vacuum Bellows, Vacuum Piping, Cryogenic Break, and Copper Joint Failure Rate Estimates for ITER Design Use, INL/EXT-10-18973, Idaho National Laboratory, June 2010.

Cadwallader, L. C., 2013a, Preliminary Failure Modes and Effects Analysis of the US Massive Gas Injection Disruption Mitigation System Design, INL/EXT-13-30212, Idaho National Laboratory, October 2013.

Cadwallader, L. C., 2013b, In-Vessel Coil Material Failure Rate Estimates for ITER Design Use, INL/EXT-13-28031, Idaho National Laboratory, January 2013.

Cadwallader, L. C., 2013c, "Failure Rate Adjustment Factors for High Technology Components," Proceedings of the 25 th IEEE/NPSS Symposium on Fusion Engineering, June 10-14, 2013.

Cadwallader, L. C., 2014, Preliminary Failure Modes and Effects Analysis of the US Shattered Pellet Injection Disruption Mitigation System Design, INL/EXT-14-31964, Idaho National Laboratory, June 2014.

Cadwallader, L. C., 2015, Preliminary Reliability, Availability, Maintainability, and Inspectability Analysis of the US Fueling Pellet Injection System Flight Tubes, INL/LTD15-34362, Idaho National Laboratory, March 2015. 
Cadwallader, L. C., 2018, Preliminary Failure Modes, Effects and Criticality Analysis of the U.S. Fueling Pellet Injection System Confinement Cask, INL/LTD-17-43433, rev. 2, Idaho National Laboratory, March 2018; ITER IDM number: ITER_D_VPB7YM.

Dexter, A. H. and W. C. Perkins, 1982, Component Failure-Rate Data with Potential Applicability to a Nuclear Fuel Reprocessing Plant, DP-1633, Savannah River Laboratory, July 1982.

Eide, S. A., T. E. Wierman, C. D. Gentillon, D. M. Rasmuson, and C. L. Atwood, 2007, Industry-Average Performance for Components and Initiating Events at U.S. Commercial Nuclear Power Plants, NUREG/CR-6928, U.S. Nuclear Regulatory Commission, Washington, DC, February 2007.

Exida, 2012, Electrical \& Mechanical Component Reliability Handbook, volume 2, mechanical components, Exida.com LLC, Sellersville, PA, 2012.

Feron, D., editor, 2012, Nuclear Corrosion Science and Engineering, Woodhead Publishing Limited, Oxford, UK, 2012, p. 57.

FIDES, 2010, FIDES Guide 2009, Edition A, Reliability Methodology for Electronic Systems, September, 2010, pp. 44-45, available at http://www.fides-reliability.org.

Fleming, K. N., and B. Lydell, 2006, Pipe Rupture Frequencies for Internal Flooding PRAs, revision 1, EPRI-TR-1013141, Electric Power Research Institute, Palo Alto, CA, 2006.

Grosselin, S. R., F. A, Simonen, S. P. Pilli, and B. O. Y. Lydell, 2007, Probabilities of Failure and Uncertainly Estimate Information for Passive Components - A Literature Review, NUREG/CR-6936, U.S. Nuclear Regulatory Commission, Washington, DC, May 2007.

Haferkamp, H., O. Meier, and K. Harley, 2007, "Laser Beam Welding of New High Strength Steels for Auto Body Construction," Key Engineering Materials, 344, pp. 723-730.

Harris, 1984, Reliability and Maintainability Data for Industrial Plants, report TD-84-3, A. P. Harris and Associates, Ottawa, Canada.

IAEA, 2000, Safety of Nuclear Power Plants: Design, Requirements, NS-R-1, IAEA, Vienna, 2000.

IEEE, 1984, IEEE Guide to the Collection and Presentation of Electrical, Electronic, Sensing Component, and Mechanical Equipment Reliability Data for Nuclear-Power Generating Stations, IEEE Std 500-1984, Institute of Electrical and Electronics Engineers, New York, December 1983.

Johnson, D. H., et al., 1988, The High Flux Isotope Reactor Probabilistic Risk Assessment, final report, PLG-0604, Pickard, Lowe, and Garrick, Inc., January 1988.

Juvinall, R. C., and K. M. Marshek, 1991, Fundamentals of Machine Component Design, second edition, New York: John Wiley \& Sons, Inc., pg. 224. 
Kirk, S., W. Suder, K. Keogh, T. Tremethick, and A. Loving, 2018, "Laser Welding of Fusion Relevant Steels for the European DEMO," Fusion Engineering and Design, in press, corrected proof, March 30, 2018.

Lauridsen, K., P. Christensen, and H. E. Kongso, 1996, “Assessment of the Reliability of Robotic Systems for Use in Radiation Environments," Reliability Engineering and System Safety, 53, pp. 265-276.

Lydell, B. O. Y., 2000, "Pipe Failure Probability-The Thomas Paper Revisited," Reliability Engineering and System Safety, 68, pp. 207-217.

Moss, T. R., 2005, The Reliability Data Handbook, New York: ASME Press, 2005.

Mahar, D., et al., 2011, Nonelectronic Parts Reliability Data 2011, NPRD-2011, Volume 1, Reliability Information Analysis Center, Utica, New York, January 2011.

Medhekar, S. R., D. C. Bley, and W. C. Gekler, 1993, "Prediction of Vessel and Piping Failure Rates in Chemical Process Plants Using the Thomas Model," Process Safety Progress, 12, pp. 123-126.

MIL-HDBK, 1991, Reliability Prediction of Electronic Equipment, MIL-HDBK-217F, US Department of Defense, Washington, DC, December 1991.

Moosemiller, M., 2006, "Avoiding Pitfalls in Assembling an Equipment Failure Rate Database for Risk Assessments," Journal of Hazardous Materials, 130, pp. 128-132.

NASA, 1971, Saturn Component Failure Rates and Failure Rate Modifiers, NASA TM X-64619, US National Aeronautics and Space Administration, Washington, DC, December 1971.

NSWC, 2010, Handbook of Reliability Prediction Procedures for Mechanical Equipment, NSWC-10, Naval Surface Warfare Center, Carderock Division, West Bethesda, Maryland, January 2010.

Prince, R., 2012, Radiation Protection at Light Water Reactors, Heidelberg, Germany: SpringerVerlag, pp. 16-19.

Scherpelz, R. I., and J. E. Tanner, 2002, "Neutron Measurements at Nuclear Power Reactors," Nuclear Instruments and Methods in Physics Research Section A, Vol. 476, pp. 400-404.

Schnauder, H., C. Nardi, and M. Eid, 1997, "Comparative Availability Analysis of the Four European DEMO Blanket Concepts in View of the Selection Exercise," Fusion Engineering and Design, 36, pp. 343-365.

Shannon, G., 2016, Laser Welding Fundamentals, Lasers Today web site, https://www.laserstoday.com/2016/07/laser-welding-fundamentals/, published July 11, 2016, web page visited September 12, 2018. 
Smith, D. J., 2017, Reliability, Maintainability and Risk, $9^{\text {th }}$ edition, Oxford, United Kingdom: Butterworth Heinemann, Appendix 4.

Thomas, H. M., 1981 "Pipe and Vessel Failure Probability," Reliability Engineering, 2, pp. 83124.

Tsoulfanidis, N., 1983, Measurement and Detection of Radiation, $1^{\text {st }}$ edition, New York: McGraw-Hill Book Company, pp. 492, 495.

Vinod, G., H. S. Kushwaha, A. K. Verma, and A. Srividya, 2004, “Optimisation of ISI Interval Using Genetic Algorithms for Risk Informed In-service Inspection,” Reliability Engineering and System Safety, 86, pp. 307-316.

Weglowski, M. St., S. Blacha, and A. Phillips, 2016, "Electron Beam Welding-Techniques and Trends-Review," Vacuum, 130, pp. 72-92.

Zinkle, S. J., and J. T. Busby, 2009, "Structural Materials for Fission and Fusion Energy," Materials Today, 12, pp. 12-19. 